CORRECTION

\title{
Correction to: Histological regression in melanoma: impact on sentinel lymph node status and survival
}

Karina Aivazian, Tasnia Ahmed, Mary-Ann El Sharouni, Jonathan R. Stretch, Robyn P. M. Saw (D), Andrew J. Spillane (iD,

Kerwin F. Shannon (D), Sydney Ch'ng (D), Omgo E. Nieweg, John F. Thompson (D), Serigne N. Lo (D) and Richard A. Scolyer (D)

(c) Crown 2021

Modern Pathology (2021) 34:2091; https://doi.org/10.1038/s41379-021-00878-8

Correction to: Modern Pathology https://doi.org/10.1038/s41379021-00870-2
The original version of this article unfortunately contained a mistake. In table 1 "Breslow thickness (categorised) (mm2)" should be "Breslow thickness (categorised) ( $\mathrm{mm})^{\prime}$. The authors apologise for the mistake. The original article has been corrected. 